\title{
Implementing the Transition to Sustainable Development
}

\author{
Eric Lambin ${ }^{*}$
}

\begin{abstract}
From 1890 to 1990, the world population increased four times over while consumption of industrial products grew 40 times, energy consumption 16, water consumption 9 and the total size of the economy 14 times.

Thanks to his creativity, man has the power to innovate and adapt his technologies, socio-political institutions and attitude towards respect for Nature in order to alleviate pressure on the environment. Markets in general do not take into account the value of many goods and services which are provided by Nature (such as the pollination of plants by insects, the regulation of floods by vegetation cover, the decomposition, by bacteria, of waste and toxic waste released into the water and soil, or the aesthetic value of the landscape).

The successful transition to sustainable development requires the combination of sound information on the state of the environment, motivation turned into action and capacity to do so.
\end{abstract}

Keywords: Economic Development; Sustainable Development; Environment Changes; Market Policies; Natural Resources Management; Negative Environmental Externalities; Global Markets

\section{Economic Development and Environment Changes}

In more recent times, humanity has transformed the planet Earth to such a point that it threatens the production by the natural world of goods and services on which the same humanity is dependent. These environmental changes have undergone considerable acceleration in the course of the twentieth century. Man's activity has pushed the earth system beyond the boundaries of its natural functioning. The natural environment's future reactions to pressures exercised by man will therefore become increasingly unpredictable. Given the complexity of the earth system, drastic changes cannot be excluded, once certain critical thresholds are passed. In particular, we should think about what would happen if, for example, rapid changes in climate occurred in conjunction with rapid changes in the political, economic or social sphere. Some regions of the world are more vulnerable than others. Humanity has

\footnotetext{
* Professor of Geography, Université Catholique de Louvain (e.lambin@uclouvain.be)
} 
embarked involuntarily on the road to a wide-ranging experience for which there is no known central management or clear vision of the destination that will be reached by the trajectory it is following.

Mutations in the natural environment are the result of decisions taken by defined players and those mutations are themselves affected by changes which have taken place in the economy, technology, institutions, politics, demographics and value systems. Environmental changes are the result of complex interaction between such factors at different levels of organization of human societies, from local to worldwide level. If we were to identify the root cause of environmental changes provoked by man, we could probably relate it to the growth in consumption, particularly driven by the search for social status and by the desire for power.

From 1890 to 1990, the world population increased four times over while consumption of industrial products grew 40 times, energy consumption 16, water consumption 9 and the total size of the economy 14 times. The current trajectory of development, if it were to be maintained without further change, would not be environmentally sustainable, particularly if the 9 billion people who will dwell in the planet in a few decades were to reach the level of consumption equivalent to that which characterizes the $20 \%$ of the planet's privileged - who today appropriate more than $80 \%$ of the value of goods and services produced in the world. However, it would be very unlikely for societies not to continue to change their relationship with the natural environment.

Thanks to his creativity, man has the power to innovate and adapt his technologies, socio-political institutions and attitude towards respect for Nature in order to alleviate pressure on the environment. Some recent developments in Western societies' technological, institutional and cultural areas suggest that it is possible to reverse the current trends. Throughout human history, many societies have managed to improve their natural environment and reverse a path of rapid degradation of the environment through policy interventions motivated by the perception of ecological risks and made possible by technological innovations and changes to the social and economic systems. Numerous ancient societies have, on the other hand, disappeared as a result of the environmental degradation they caused, in particular because the ruling class did not grasp, anticipate or understand the nature of such impairment, had no interest in responding or did not do so because there was no capacity to innovate at a technological, institutional or economic level. The successful transition to sustainable development requires the combination of sound information on the state of the environment, motivation turned into action and capacity to do so.

There are two falsehoods underlying an irresponsible attitude of nonintervention: first, the idea that new technologies, alone, will solve future environmental problems; and second, that, in the absence of regulation, market mechanisms will spontaneously create the stimuli for the adoption of production technologies with reduced environmental impact. In reality, technological progress, which allows, for example, the miniaturization, the lightening of materials ('dematerialization') and the recycling of many products, as well as the decrease in the intensity of their energy consumption and, therefore, the reduction in pollution associated with these products, is often accompanied by a more than proportional increase in their demand by consumers (through the so-called 'rebound effect'): new cars are lighter and consume less fuel, but the planetary car park increases 
rapidly, as do the distances travelled by each vehicle. This often undoes the positive effects of technological progress on the environment. There is nothing that guarantees that new technologies will reduce the worldwide impact of human activity on the earth system - considering also developing countries - before irreversibly overstepping the critical thresholds (such as the extinction of animal or plant species useful for the functioning of ecosystems). On the other hand, markets in general do not take into account the value of many goods and services which are provided by Nature (such as the pollination of plants by insects, the regulation of floods by vegetation cover, the decomposition, by bacteria, of waste and toxic waste released into the water and soil, or the aesthetic value of the landscape). Finally, market mechanisms, when they are not regulated, sometimes lead to the export of pollution to developing countries, which represent $80 \%$ of the world population.

The innovations necessary to rebalance human activity and natural processes are not carried out spontaneously. The adaptation of human societies to changes in the environment is the result of shrewd political intervention. Such policies must have the goal, in regions with advanced economies, of stimulating the development and adoption of more eco-efficient technologies (that is, able to maximize the productivity of natural resources and minimize pollution per unit of economic product), encouraging the consumption of goods at lower levels of energy and material consumption (goods whose production has a lower environmental impact), while satisfying, nevertheless, the same overall needs. In developing countries, prime objectives should include the transfer of clean technologies (to cut the trajectory that, in industrialized countries, took more than a century to switch from highly polluting production systems to cleaner technologies). Even the creation of conditions to facilitate a demographic transition towards world population stabilisation will have a healthy effect on the planet's environment. We must have, therefore, a moral imperative that underlies these policies: to ensure a fairer distribution of wealth worldwide.

The means at our disposal to achieve these goals are at the same time institutional reforms (in the broadest sense, namely the set of rules, decision-making procedures and programs that define social action) and the creation of a new order of values which advocates a greater sense of responsibility towards the world and future generations. However, how to conceive an institutional and cultural environment that encourages private actors to bear short-term costs in order to create long-term benefits for the community? For businesses, how to transform this short-term cost into competitive advantage, whilst also creating - as often as possible - 'win-win' situations? How to influence behaviour leaving a great degree of freedom and flexibility to private players during this transition? We must implement a wide range of complementary strategies.

\section{Market Policies and Sustainable Development}

The use of market mechanisms by modifying the game rules allows us to reconcile the long-term quest for individual interest with the public good: subsidies for environmentally sound practices (direct transfers to producers or consumers, application of preferential tax regimes), taxes on pollution and waste (tax on the 
percentage of carbon in fuels), certification related to environmental management quality, the creation of new markets for services provided by natural ecosystems (through the allocation of exchangeable pollution quotas, etc.). This flexible approach must be superseded by a more interventionist approach through environmental legislation that encourages private players to respect the environment (environmental standards), establishes sanctions for environmentally destructive practices, regulates the right of entry of firms in specific sectors that are environmentally sensitive, or that bans products or materials harmful to the environment.

International conventions on the environment should promote the transfer of clean technologies to developing countries but also prevent the flight of businesses to countries with lenient environmental standards, by defining common rules on an international scale. These conventions, however, often depend on endless negotiations before they are introduced, in a context of limited resources, bureaucratic complexity in their implementation and the refusal of some of the biggest culprits on the environment to ratify them.

Here are some measures that could easily be implemented on a large scale and have an immediate effect on the decisions of the players involved in the natural environment. The first four measures make use of classic economic policy tools and, as such, could be quickly implemented.

1. Identify and then remove the unreasonable subsidies that encourage degradation in the environment or penalize the introduction of cleaner technologies. Particularly in the areas of road transport, agriculture, production of energy from fossil fuels, water consumption, fisheries and forest exploitation.

2. Include in product prices their social cost (the 'negative environmental externalities'), that is, adjust the price of products to their actual cost, including the costs which their production and consumption inflict on the environment, through taxes on the consumption of certain products.

3. Gradually replace taxes on earned income and capital taxes with taxes on the extraction of resources and on pollution, on an equal volume of taxation basis. It would be in the interest of businesses to decrease consumption of non-renewable resources and renounce polluting factors by increasing the use of the workforce. New workers would have responsibility for the recycling of waste and components and some engineers would specialize in finding solutions to reduce energy consumption. The speed of resolving environmental problems would match the increase in work.

4. In national accounts and project evaluations, no longer consider depletion or degradation of natural resources as income but as capital erosion. This measure will have an impact on economic policies by stimulating growth and exports, and will have an effect on decisions concerning investment in certain infrastructures.

The following four measures require coordinated action at an international scale and the mobilization of substantial financial resources.

5. Promote the increased spread of advanced and less polluting technologies by foreign investors to the poorest countries, stimulate knowledge transfer and develop programs to finance and train experts from developing countries. 
6. Run the equivalent of a 'Manhattan Project' on an international scale for the production, distribution, storage and conversion of clean and renewable energy by piloting a portfolio of diversified technologies.

7. Invest in the safeguarding, regeneration and increase of natural capital. For example, invest in maintaining fish populations through implementation of oceanic reserves rather than investing to increase fishing fleet capacity.

8. Create the conditions for population growth control in developing countries, above all, by improving the status of women, education and economic development.

The last four measures are directed towards a longer-term time horizon since they concern fundamental aspects in the functioning of contemporary society.

9. Improve governance in natural resource management through an effective fight against corruption and wastage in the product processing and distribution chain.

10. Better coordinate natural resource management policies between power levels (vertical interaction) and between activity sectors (horizontal interaction).

11. Stimulate creativity and inventiveness for a successful transition to sustainable development through educational programs and through an organized and efficient integration of the concept of sustainable development in training (engineers, managers, lawyers, etc.), research and development programs.

12. Promote a new consumption model based on the quality of life rather than on the quantity of material goods consumed, and change the social perception that confers high social status to the consumption of goods with high material and energy content. This requires, among others, to sublimate the human need for material goods to a superior level of needs. The latter measure is the most difficult to achieve, but also the most important for the future of the planet and humanity: forging a new order of values that can be adopted and respected everywhere and which reflects a sense of belonging in the world.

These measures are mostly already operating at different levels, but are implemented at too slow a pace in relation to the speed of environmental change. The transition to sustainable development requires many decades. Today, given the vastness of the world and the unprecedented speed of environmental changes, the inertia of natural and social systems and the growing complexity of the economies in the era of globalisation, a correction of human activities must take place on a preventive basis in the face of an environmental crisis. The objective has be that of carrying out the transition to sustainable development within the next fifty years. The twenty-first century will be a bottleneck in the history of humanity: a century at the opening of which the extraordinary technological and economic progress of the twentieth century, and an unprecedented population growth, will not have been matched yet by the institutional capacity and the wisdom to manage the interaction between these two complex and interdependent systems: planet Earth and the global socio-economic system. 
To carry out such a social project (and humanity has no other option if it wants to avoid being ashamed of the world that it will leave to future generations), we must find the right balance between small progressive reforms and radical changes to our most basic forms of production and consumption, and between the prevention of environmental crises, the adaptation to changes already underway, and the repair of damage already inflicted on the earth system. We must also overcome numerous obstacles. The first concerns global governance: at what level of power to intervene? What balance between centralization of political decisions on an international scale and decentralization to a level of power more able to respond to environmental degradation will guarantee that democracy is maintained indispensable, and a sine qua non in obtaining the support of all? A second obstacle concerns the absence of strong willingness on the part of leaders to risk popularity for a long-term political project, to which can be added the active resistance of pressure groups who defend the interests of specific sectors, not without maintaining sometimes privileged links with certain leaders.

Finally, a considerable effort in education and information will be required to overcome inertia in how individuals behave. A severe increase in the awareness of the risks associated with environmental change and a rapid reaction with appropriate policies are indispensable to find a route for sustainable development. To begin an alternative way of inhabiting the Earth - one that is in harmony with its diversity, complexity and beauty - is not only the responsibility of each and every one of us, but also in our power to do so.

\section{Bibliography}

Ausubel J.H., Langford H.D. (ed.), Technological Trajectories and the Human Environment, National Academy Press, Washington D.C., 1997.

Daily G.C., Ellison K., The New Economy of Nature: The Quest to Make Conservation Profitable, Island Press, Washington D.C., 2002.

Daly E.D., Five Policy Recommendations for a Sustainable Economy, Schor J.B., Taylor B. (ed.), Sustainable Planet. Solutions for the Twenty-First Century, Beacon Press, Boston, 2003.

Havel V., Les flèches du renouveau, Publié dans des journaux quotidiens par Project Syndicate, 2000.

Hawken P., Lovins A., Lovins L.H., Natural Capitalism Creating the Next Industrial Revolution, Little, Brown and Company, Boston, New York, 1999.

McNeill J.R., Something New Under the Sun. An Environmental History of the Twentieth-Century World, W.W. Norton \& Company Inc., New York, 2001.

Myers N., Kent J., Perverse Subsidies. How Tax Dollars Can Undercut the Environment and the Economy, Island Press, Washington D.C., 2001.

Redman C.L., Human Impact on Ancient Environments, University of Arizona Press, Tucson, 1999, p. 288.

Steffen W., Sanderson A., Tyson P.D., Jäger J., Matson P., et al., Global Change and the Earth System: A Planet Under Pressure, Springer, Berlin, 2004. 